\title{
Investigation of FeN and TiN thin films properties for possible application in electronic devices
}

\author{
Investigação das propriedades de filmes finos de FeN e TiN para \\ possível aplicação em dispositivos eletrônicos
}

Júlio Fernando Sousa de Carvalho', Bartolomeu Cruz Viana Neto², José Weliton Nogueira Júnior ${ }^{1 *}$, Heurison de Sousa e Silva²,

Wênio Fhará Alencar Borges ${ }^{1,3}$, Rômulo Ribeiro Magalhães de Sousa ${ }^{1}$

\section{ABSTRACT}

In the present work, thin films of FeN (Iron Nitride) and TiN (Titanium Nitride) were deposited in samples of laminated glass by cathodic cage deposition technique using stainless steel and titanium cages, respectively. Scanning Electron Microscopy (SEM), Energy Dispersive X-ray Spectroscopy (EDS), Wettability and Electrical Conductivity techniques were used to characterize the samples. To obtain the electrical conductivity values, the electrical resistivity (also known as specific electrical resistance) was calculated. In this way, the lower the resistivity, the easier is the passage of an electric charge through the material. To this purpose, it was used the four-point probes method. FeN film presented hydrophobic surface, and TiN film hydrophilic surface. Both films were promising in electrical conductivity analysis. The results show promise applications in the electronic devices.

Keywords: Plasma, Thin films, Cathodic cage.

\section{RESUMO}

No presente trabalho, filmes finos de FeN (nitreto de ferro) e TiN (nitreto de titânio) foram depositados em amostras de vidro laminado pela técnica de deposição de gaiola catódica utilizando gaiolas de aço inoxidável e titânio, respectivamente. Técnicas de Microscopia Eletrônica de Varredura (MEV), Espectroscopia de Raios-X por Dispersão de Energia (EDS), Molhabilidade e Condutividade Elétrica foram utilizadas para caracterizar as amostras. Para obter os valores de condutividade elétrica, fo calculada a resistividade elétrica (também conhecida como resistência elétrica específica). Desta forma, quanto menor a resistividade, mais fácil é a passagem de uma carga elétrica através do material. Para isso, utilizou-se o método de sondas de quatro pontas. O filme de FeN apresentou superfície hidrofóbica e o filme de TiN, superfície hidrofílica. Ambos os filmes foram promissores na análise de condutividade elétrica. Os resultados mostram aplicações promissoras nos dispositivos eletrônicos.

Palavras-chave: Plasma, filmes finos, gaiola catódica.

1.Universidade Federal do Piauí - Centro de Tecnologia - Laboratório de Plasma - Teresina/PI - Brazil.

2.Universidade Federal do Piauí - Centro de Ciências Naturais - Departamento de Física - Teresina/PI - Brazil.

3.Universidade Federal do Maranhão - Departamento de Engenharia Mecânica - São Luís/MA - Brazil.

Autor correspondente: josenogueira121@gmail.com

Recebido: Feb. 7, 2019 Aprovado: Feb. 22, 2019 


\section{INTRODUCTION}

In recent years, with advances in electronics technology and the beginning of research on the field of nanotechnologies, plasma deposition using the cathodic cage technique (hollow-cathode effect) is one of the processes of surface coating that provides the improvement of certain mechanical and chemical properties of the surface of various materials, being responsible for innovative technological applications ${ }^{1}$. Through this technique of plasma deposition, a cathodically polarized screen surrounds the samples, being possible to obtain uniform and continuous layers, even in samples with complex geometries ${ }^{2,3}$.

In this process, the sample is confined inside the chamber, which is previously evacuated, maintaining a controlled flow of a gaseous mixture of $\mathrm{N}_{2}-\mathrm{H}_{2}$ to produce the plasma. The same process is achieved in an abnormal discharge regime by applying an electric voltage of the order of 300 to 1000 VDC, between the sample (cathode) and the anode, which is generally the inner wall of the chamber. The cage is heated during the process by ion bombardment with sufficient temperature to cause the detachment of the atoms present in its crystalline lattice. Concomitantly, a complex series of chemical reactions occurs at the interface that give rise to the different phases of nitrites forming layers of deposits on the surface of the sample ${ }^{4}$.

Recently, FeN thin films have been widely investigated for their variety of structures and magnetic properties ${ }^{5}$. As for TiN, it has high melting point $\left(3160-3250{ }^{\circ} \mathrm{C}\right)$, high hardness (2500-3000 HV), thermal and chemical stability, wear and corrosion resistance, and some metallic properties, such as low coefficient of friction and high thermal and electrical conductivity. Due to the presence of those properties, there is a great applicability of this technology in microelectronics ${ }^{6,7}$. The similarity of TiN in color with yellow gold is considered an important quality already explored in the watchmaking industry ${ }^{8}$.

Thin films play an essential role in devices and integrated circuits. They are used in the connections of the active regions of a device in the communication between them, in the external access to the circuits to isolate conductive layers, as structural elements of the devices to protect the surfaces of the external environment, as a dopant source, and as a barrier for doping. The thin films may be conductors, semiconductors or insulation, usually thermally grown or deposited from the vapor phase ${ }^{9}$. Additionally, thin films are used in the microelectronics industry to make films serving as dielectrics, conductors, passivation layers, oxidation barriers, and epitaxial layers ${ }^{10}$.

The study of wetting behavior by measuring the angle that the drop of a fluid forms with the surface on contacting the solid - called contact angle - is one of the important aspects in the interfacial properties of materials. Thus, the wettability of a material represents the ability of a liquid to maintain contact with the solid surface resulting from intermolecular interactions when the two are placed together. When the bonding forces to the surface of the solid are very large relative to the cohesive forces, it is named hydrophilic surface, and when the contact angle is less than 90 degrees, the liquid wets the surface. Therefore, when the contact angle tends to be lower, the wettability of the surface tends to be greater $^{11}$.

In this context, the objective of this work was to deposit plasma films by plasma technique using the cathodic cage deposition technique and varying the parameters that influence film deposition, such as: exposure time, chamber pressure, and chamber atmosphere and temperature, in order to obtain films of good quality in relation to their electrical properties. Films in the samples were characterized using the following techniques: Scanning Electron Microscopy (SEM), Energy Dispersive X-ray Spectroscopy (EDS), Wettability and Electrical Conductivity.

\section{MATERIALS AND METHODS}

\section{Materials}

Firstly, simple glass substrates with dimensions of $25 \times 25 \mathrm{~mm}$ were cleaned with two different solutions: initially with $10 \% \mathrm{KOH}$, and then with $10 \% \mathrm{HNO}_{3}$. After that, it was used acetone in an ultrasonic bath before placing it in the plasma reactor chamber. In the cathodic cage ion deposition, it was used the same conventional nitriding equipment. The vacuum chamber is made of AISI 316 austenitic stainless steel. Two cages of different materials were added: one of stainless steel to obtain FeN, and another of titanium to obtain TiN.

\section{Treatment conditions}

The treatment conditions are presented in Table 1, with: temperature, time, pressure, and gas atmosphere.

Table 1: Process parameters used in the deposition of nitrides.

\begin{tabular}{|c|r|r|c|c|}
\hline Sample & Temperature & Pressure & Gas atmosphere & Time \\
\hline FeN & $400{ }^{\circ} \mathrm{C}$ & 1.5 Torr & $\mathrm{H}_{2} / \mathrm{N}_{2}(40 / 120 \mathrm{sccm})$ & $2 \mathrm{~h}$ \\
\hline $\mathrm{TiN}$ & $350^{\circ} \mathrm{C}$ & $1.5 \mathrm{Torr}$ & $\mathrm{H}_{2} / \mathrm{N}_{2}(75 / 25 \mathrm{sccm})$ & $3 \mathrm{~h}$ \\
\hline
\end{tabular}

The sample was placed on an alumina insulation disk, as shown in Fig. 1a. The voltage source used was pulsed. The flow of gases is controlled by means of flow controllers. Plasma is formed in the cathodic cage (Fig. 1b), which functions as cathode (the wall of the chamber is the anode), and not directly on the surface of the samples, which remain floating potential, positioned on an insulating surface ${ }^{4}$. 
(A) '

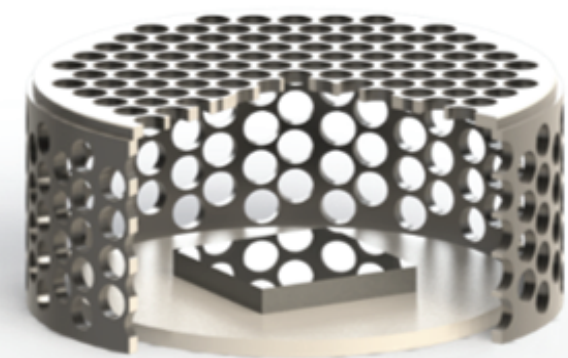

(B)

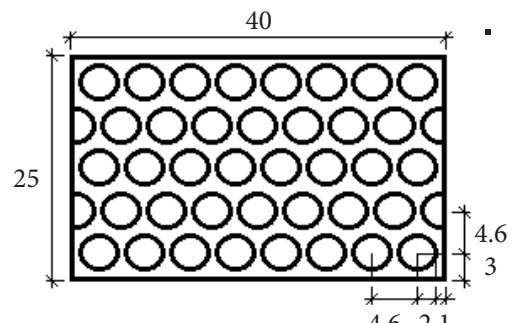

Scale $1 / 2$

Units: $\mathrm{mm}$

Figure 1: (A) Arrangement of the sample inside the cathodic cage with the insulating disk of alumina; and (B) Schematic drawing (2D) of the cathodic cage.

\section{METHODOLOGY}

Samples were characterized in order to probe the possible changes on the surface due to the action of the plasma. Thus, the characterization of techniques used in this work is described.

\section{Wettability}

The wettability measurements were determined through the contact angle of one drop of distilled water with $16 \mu \mathrm{L}$ in volume using the CAM2008 program (KSV Instruments). The sessile drop method was chosen to this technique. Drop water images were obtained with a CCD camera that captured twenty images. The value of the contact angle is the mean of the twenty measures with the standard deviation.

\section{Electrical Conductivity}

To measure the electrical conductivity, it was used the fourpoint probes method (see, for instance Giorotto and Santos ${ }^{12}$ ), where four electrodes were arranged linearly and equally spaced. Current was injected through two of the electrodes and then, voltage measurements were taken on the other two. The most common configuration was to use the two external electrodes to inject current and the two internal ones to measure the voltage drop, but in principle, any of the possible combinations can be used.

In the case where the tips with varied spacing are on a semiinfinite surface, it can be proved that the resistivity is given by Eq. 1:

$$
\rho=\frac{2(\mathrm{~V} / \mathrm{i})}{\left[\frac{1}{s 1}+\frac{1}{s 3}-\frac{1}{s 1+s 2}-\frac{1}{s 2+s 3}\right]}
$$

where: $s 1, s 2$, and $s 3$ are the spacing between the tips, and $V$ and $i$ are the measured voltage $(\mathrm{mV})$ and the current $(\mathrm{mA})$ injected, respectively. In this case, $s$ is the distance between the tips, equal to $1.5 \mathrm{~mm}$. For this work, it was noted that the tips are equally spaced $(s=s 1=s 2=s 3)$, thus, Eq. 1 for resistivity reduces to the following form (Eq. 2):

$$
\rho=2 \pi s\left(\frac{V}{i}\right)
$$

In this work, for the samples with possible deposition of FeN and $\mathrm{TiN}$, the resistivity measurements by the four-point probes method were obtained in two different positions, as shown in Fig. 2. The samples of squared format have dimensions of $25 \times 25 \mathrm{~mm}$ and height of $12.5 \mathrm{~mm}$.

(A)

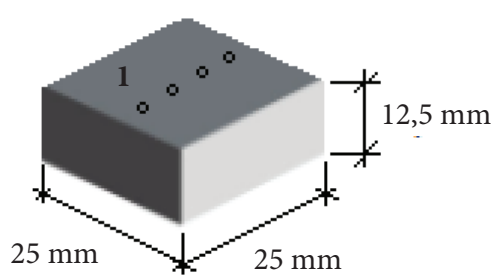

(B)

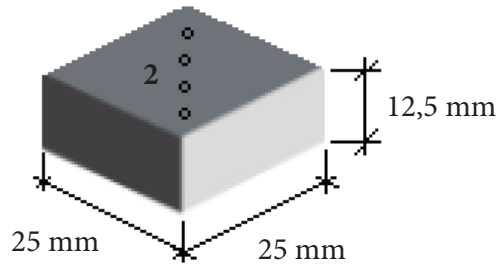

Figure 2: Resistivity measurements using the 4-point probes method at: (A) position 1, and (B) position 2, for the samples with possible deposition of FeN and TiN.

\section{Scanning Electron Microscope (SEM) and Energy-Dispersive Spectrometer (EDS)}

The Scanning Electron Microscope (SEM) permits the observation and characterization of heterogeneous organic and inorganic materials on a nanometer $(\mathrm{nm})$ to micrometer $(\mu \mathrm{m})$ scale. The popularity of the SEM stems from its capability of obtaining three-dimensional-like images of the surfaces of a very wide range of materials. In the SEM, the area to be examined or the microvolume to be analyzed is irradiated with a finely focused electron beam, which may be swept in a raster across the surface of the specimen to form images or may be static to obtain an analysis at one position ${ }^{13,14}$. In this paper, the SEM is from the Quanta 250 FEG model (FEI company brand), in which it has an attached EDS module. 


\section{RESULTS AND DISCUSSIONS}

Figures 3 and 4 present images obtained by the SEM of the film surface deposited in a cathodic cage on glass substrate. It is evident the formation of a layer with small grains on the surface of the substrate. It is possible to treat nitrides formed by the interaction of the cage with the ionized nitrogen ${ }^{15}$. It is also possible to observe a uniform coverage formed by particles with random distribution. Such particles are formed due to the agglomeration of nitrides and iron particles ${ }^{16}$.

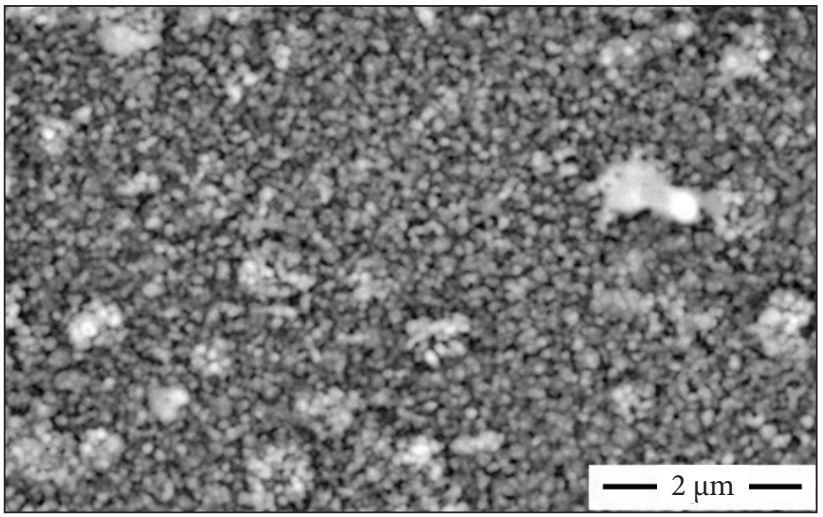

Figure 3: SEM image of the glass sample surface treated with stainless steel cage $(50.000 \times$ magnification $)$.

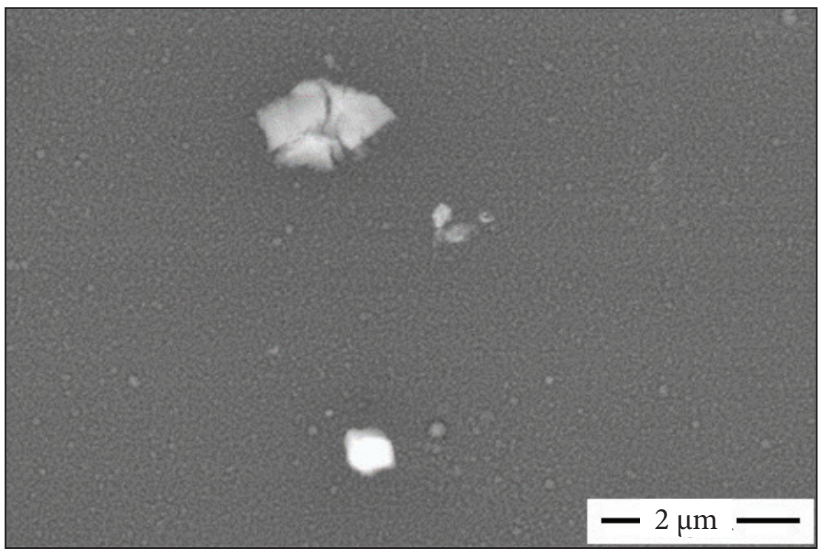

Figure 4: SEM image of the glass sample surface treated with titanium cage (50.000 $\times$ magnification).

In Fig. 4, there is the glass surface treated with titanium cage and it is observed a structure similar to films of titanium nitride ${ }^{17}$. When compared to the samples treated with steel cage, a more uniform and regular structure of the formed film is observed. In contrast, the first film does not show as thick as the second one ${ }^{18}$.

In the EDS analysis of the glass sample treated with steel cage, it is possible to observe the presence of chemical elements as nitrogen and iron assuming the presence of iron nitride in the film composition. Table 2 shows the chemical elements as weight and atomic results. It can be observed the high concentration of iron in the sample. The other constituents are present due to the composition of the cage and the atmosphere that is rich in nitrogen.
Table 2: EDS results of the sample with possible deposition of iron nitride.

\begin{tabular}{|c|c|c|}
\hline Element & Weight (\%) & Atomic (\%) \\
\hline Iron (Fe) & 61.0 & 43.4 \\
\hline Nitrogen (N) & 5.1 & 14.5 \\
\hline Chromium (Cr) & 11.9 & 9.1 \\
\hline Nickel (Ni) & 11.0 & 7.5 \\
\hline Carbon (C) & 2.1 & 6.9 \\
\hline
\end{tabular}

Table 3 shows the EDS result of the sample deposited with titanium cage. There is a considerable amount of titanium and nitrogen elements obtained through the plasma deposition process that shows the possible formation of the compound TiN. It is observed a smaller amount of the forming elements, when it is compared to the deposition result obtained with the steel cage (Table 2), evidencing that the film made of $\mathrm{FeN}$ is much thicker than the $\mathrm{TiN}_{\text {film}}$. It was observed the presence of the carbon element (not present in the cage), which may appear in the EDS analysis due to some contamination of the system.

Table 3: EDS results of the sample with possible deposition of titanium nitride.

\begin{tabular}{|c|c|c|}
\hline Element & Weight (\%) & Atomic (\%) \\
\hline Nitrogen $(\mathrm{N})$ & 19.0 & 29.2 \\
\hline Titanium $(\mathrm{Ti})$ & 16.0 & 7.2 \\
\hline Chromium $(\mathrm{Cr})$ & 0.2 & 0.1 \\
\hline Carbon $(\mathrm{C})$ & 3.8 & 6.8 \\
\hline
\end{tabular}

The values of the contact angle presented values of $\theta=78.68^{\circ}$ $\pm 0.29^{\circ}$ to $\mathrm{FeN}$ and $\theta=14.89^{\circ} \pm 0.48^{\circ}$ to TiN. Figure 5 shows the great difference in the wettability of the surfaces evidencing that FeN is less hydrophilic than TiN, which showed great wettability.

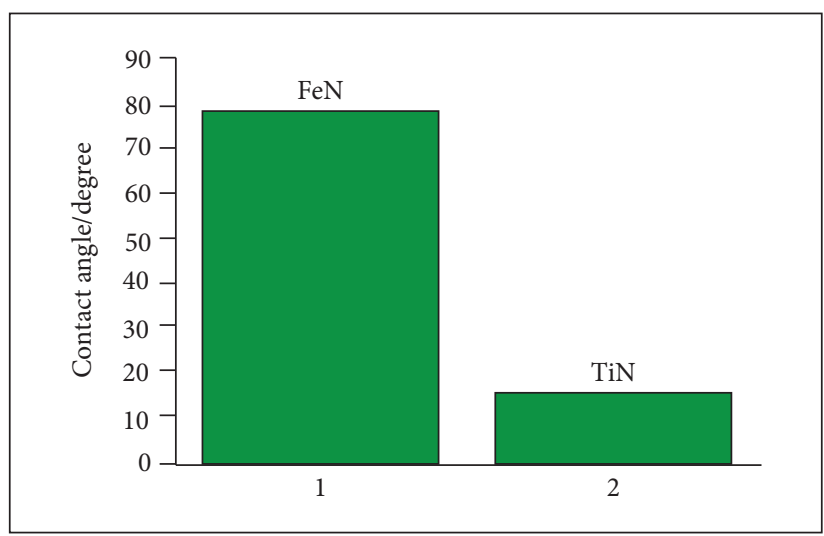

Figure 5: Contact angle values for films obtained from FeN and TiN. The error bars refer to the average of twenty measurements performed.

Tables 4, 5, 6 and 7 show the conductivity values obtained through the resistivity in the samples with possible deposition 
of FeN and TiN. Each table shows the data collected from the measurements performed at two different positions in the same sample.

Table 4: Measurements obtained by the four-point probes method at position 1, for the sample with possible deposition of FeN.

\begin{tabular}{c|c|c|c|}
\hline $\begin{array}{c}\text { Current } \\
(\mathrm{mA})\end{array}$ & $\begin{array}{c}\text { Voltage } \\
(\mathrm{mV})\end{array}$ & $\begin{array}{c}\text { Resistivity } \\
(\Omega \mathrm{m})\end{array}$ & $\begin{array}{c}\text { Conductivity } \\
(\Omega \mathrm{m})^{-1}\end{array}$ \\
\hline 10 & 0.26 & $2.45 \mathrm{E}-04$ & $4.08 \mathrm{E}+03$ \\
\hline 20 & 0.53 & $2.50 \mathrm{E}-04$ & $4.01 \mathrm{E}+03$ \\
\hline 30 & 0.80 & $2.51 \mathrm{E}-04$ & $3.98 \mathrm{E}+03$ \\
\hline 40 & 1.07 & $2.52 \mathrm{E}-04$ & $3.97 \mathrm{E}+03$ \\
\hline 50 & 1.33 & $2.51 \mathrm{E}-04$ & $3.99 \mathrm{E}+03$ \\
\hline 60 & 1.60 & $2.51 \mathrm{E}-04$ & $3.98 \mathrm{E}+03$ \\
\hline 70 & 1.86 & $2.50 \mathrm{E}-04$ & $4.00 \mathrm{E}+03$ \\
\hline
\end{tabular}

Table 5: Measurements obtained by the four-point probes method at position 2, for the sample with possible deposition of FeN.

\begin{tabular}{c|c|c|c|}
\hline $\begin{array}{c}\text { Current } \\
(\mathbf{m A})\end{array}$ & $\begin{array}{c}\text { Voltage } \\
(\mathbf{m V})\end{array}$ & $\begin{array}{c}\text { Resistivity } \\
(\Omega \mathbf{m})\end{array}$ & $\begin{array}{c}\text { Conductivity } \\
(\Omega \mathrm{m})^{-1}\end{array}$ \\
\hline 10 & 0.38 & $3.58 \mathrm{E}-04$ & $2.79 \mathrm{E}+03$ \\
\hline 20 & 0.77 & $3.63 \mathrm{E}-04$ & $2.76 \mathrm{E}+03$ \\
\hline 30 & 1.16 & $3.64 \mathrm{E}-04$ & $2.75 \mathrm{E}+03$ \\
\hline 40 & 1.63 & $3.84 \mathrm{E}-04$ & $2.61 \mathrm{E}+03$ \\
\hline 50 & 3.00 & $5.65 \mathrm{E}-04$ & $1.77 \mathrm{E}+03$ \\
\hline 60 & 4.80 & $7.54 \mathrm{E}-04$ & $1.33 \mathrm{E}+03$ \\
\hline 70 & 6.70 & $9.02 \mathrm{E}-04$ & $1.11 \mathrm{E}+03$ \\
\hline
\end{tabular}

Table 6: Measurements obtained by the four-point probes method at position 1, for the sample with possible deposition of TiN.

\begin{tabular}{c|c|c|c|}
\hline $\begin{array}{c}\text { Current } \\
(\mathbf{m A})\end{array}$ & $\begin{array}{c}\text { Voltage } \\
(\mathbf{m V})\end{array}$ & $\begin{array}{c}\text { Resistivity } \\
(\Omega \mathrm{m})\end{array}$ & $\begin{array}{c}\text { Conductivity } \\
(\Omega \mathrm{m})^{-1}\end{array}$ \\
\hline 10 & 0.74 & $6.97 \mathrm{E}-04$ & $1.43 \mathrm{E}+03$ \\
\hline 20 & 1.84 & $8.67 \mathrm{E}-04$ & $1.15 \mathrm{E}+03$ \\
30 & 5.24 & $1.65 \mathrm{E}-03$ & $6.08 \mathrm{E}+02$ \\
\hline 40 & 8.63 & $2.03 \mathrm{E}-03$ & $4.92 \mathrm{E}+02$ \\
\hline
\end{tabular}

Table 7: Measurements obtained by the four-point probes method at position 2, for the sample with possible deposition of TiN.

\begin{tabular}{c|c|c|c|}
\hline $\begin{array}{c}\text { Current } \\
(\mathbf{m A})\end{array}$ & $\begin{array}{c}\text { Voltage } \\
(\mathbf{m V})\end{array}$ & $\begin{array}{c}\text { Resistivity } \\
(\Omega \mathbf{m})\end{array}$ & $\begin{array}{c}\text { Conductivity } \\
(\Omega \mathbf{m})^{-1}\end{array}$ \\
\hline 10 & 1.16 & $1.09 \mathrm{E}-03$ & $9.15 \mathrm{E}+02$ \\
20 & 4.51 & $2.12 \mathrm{E}-03$ & $4.71 \mathrm{E}+02$ \\
30 & 8.30 & $2.61 \mathrm{E}-03$ & $3.84 \mathrm{E}+02$ \\
\hline 40 & -- & -- & -- \\
\hline
\end{tabular}

In order to compare the conductivity of the deposited film with the pure material, values of electrical conductivity for all the materials used in the treatment are presented in the Table 8. However, we have to consider that the pure material was not deposited, but a combination with nitrogen, in this way, it was obtained materials with conductivity values close to, but not exactly the values of the pure material.

Table 8: Reference values of electrical conductivity.

\begin{tabular}{c|c}
\hline Material & Conductivity \\
\hline Pure iron & 10.2 \\
\hline Titanium & $2.6 \mathrm{E} 6$ \\
\hline Glass & Between $1 \mathrm{E}-10$ and $1 \mathrm{E}-14$ \\
\hline
\end{tabular}

In the samples with $\mathrm{TiN}$ deposition at position 1 , it was obtained resistivity values up to a current of $40 \mathrm{~mA}$, but in the lowest values, the measured voltage would already exceed the equipment's comprehension value (the reading limit of the equipment), which was $10 \mathrm{mV}$. Already in position 2, in the same sample, we only could obtain voltage values up to a current of $30 \mathrm{~mA}$ within the established current range that it was $10 \mathrm{~mA}$.

According to the electrical conductivity values of both iron and pure titanium, it was possible to obtain a comparison between the pure material and its combination with the nitrogen using the cage deposition technique.

In the wettability analysis, TiN presented characteristics of a hydrophilic surface. When a drop liquid falls on the surface it tends to spread, although in the analysis of electrical conductivity, it did not have as good results as the FeN. The results obtained prove that the conductivity increases proportionally as the current increases; this is because the percolation of the current in the film depends on the nature of the internal grains of the TiN film.

\section{CONCLUSIONS}

We observed that FeN and TiN films showed distinct characteristics regarding the surface. The FeN film presented a characteristic of hydrophobic surface, not allowing the liquid to spread. On the other hand, the TiN film presented characteristics of a hydrophilic surface, which allows the liquid to be scattered. Both films were promising in electrical conductivity analysis. The obtained results show that the conductivity increases proportionally as the current increases, as also seen in Vasu et $a l{ }^{19}$. This is due to the fact that the percolation of the current in the film depends on the nature of the internal grains of the TiN film. The results found in this work show promise for future applications in the electronic devices.

\section{REFERENCES}

1. De Sousa RRM, Sato PS, Viana BC, Alves Jr. C, Nishimoto A Nascente PAP. Cathodic cage plasma deposition of $\mathrm{TiN}$ and $\mathrm{TiO} 2$ thin films on silicon substrates. Journal of Vacuum Science \& Technology A: Vacuum, Surfaces, and Films. 2015;33(4):041502. https://doi.org/10.1116/1.4919770 
2. Sousa RRM, De Araújo FO, Costa JAP, Nishimoto A, Viana BC, Alves Jr. C. Deposition of $\mathrm{TiO} 2$ film on duplex stainless steel substrate using the cathodic cage plasma technique. Materials Research. 2016;19(5):1207-1212. https://doi.org/10.1590/19805373-MR-2015-0358

3. Sousa RRM, Araújo FO, Ribeiro KJB, Sousa RS, Barbosa JCP, Alves Jr. C. Nitretação iônica em gaiola catódica do aço inoxidável martensítico AISI 420. Revista Matéria. 2008;13(1):104-109.

4. Araújo FO, Sousa RRM, Costa JAP, Alves Jr. C. Deposição de filme metálico em amostras de vidro em gaiola catódica. Revista Brasileira de Aplicações de Vácuo. 2009;27(3):149152. https://doi.org/10.17563/rbav.v27i3.442

5. Moura JAS. Filmes manométricos de FeN e AIN crescidos por sputtering e aplicações do efeito peltier [Teses de Doutorado]. Natal: Universidade Federal do Rio Grande do Norte; 2010.

6. Mezger PR, Creugers NHJ. Titanium nitride coatings in clinical dentistry. Journal of Dentistry. 1992;20(6):342-344. https://doi. org/10.1016/0300-5712(92)90021-4

7. Fouilland L, Imhoff L, Bouteville A, Benayoun S, Remy JC, Perrière $\mathrm{J}$, Morcrette M. Composition and tribological characterization of chemically vapour-deposited TiN layer. Surface and Coatings Technology. 1998;100-101:146-148. https://doi.org/10.1016/ S0257-8972(97)00604-X

8. Medeiros TVR. Comparação entre técnicas de nitretação em cátodo oco e gaiola catódica na deposição de TiN [Dissertação de Mestrado]. Natal: Universidade Federal do Rio Grande do Norte; 2014.

9. Tatsch PJ. Deposição de filmes finos. Oficina de microfabricação: projeto e construção de Cl's MOS. Campinas: Centro de componentes semicondutores da Universidade Estadual de Campinas; 2006.

10. Martin PM, Carlsson JO. Chemical vapor deposition. Handbook of deposition technologies for films and coatings. 3rd ed. Burlington-MA: Elsevier; 2010.

11. Luz AP, Ribeiro S, Pandolfelli VC. Artigo revisão: uso da molhabilidade na investigação do comportamento de corrosão de materiais refratários. Cerâmica. 2008;54(330):174-183. https://doi.org/10.1590/S0366-69132008000200007

12. Girotto EM, Santos IA. Medidas de resistividade elétrica DC em sólidos: como efetuá-las corretamente. Química Nova. 2002;25(4):639-647. https://doi.org/10.1590/S0100$\underline{40422002000400019}$

13. Goldstein JI, Newbury DE, Echlin P, Joy DC, Lyman CE, Lifshin E, Sawyer L, Michael JR. Scanning Electron Microscopy and X-ray Microanalysis. 3rd ed. New York: Kluwer Academic/ Plenum Publishers; 2003.

14. Goodhew PJ, Humphreys J, Beanland R. Electron Microscopy and Analysis. 3rd Ed. London: Taylor and Francis Books; 2000. https://doi.org/10.1201/9781482289343

15. Silva SS, Bottoni CLR, Gontijo LC, Ferreira SO. Plasma deposition of titanium nitride thin films under the effect of hollow cathode length in cathodic cage. Revista Matéria. 2017;22(3):e11857. https://doi.org/10.1590/s1517-707620170003.0191

16. Kurelo BCES, Souza GB, Silva SLR, Daudt NF, Alves Jr. C, Torres RD, Serbena FC. Tribo-mechanical features of nitride coatings and diffusion layers produced by cathodic cage technique on martensitic and supermartensitic stainless steels. Surface and Coatings Technology. 2015;275:41-50. https://doi.org/10.1016/j. surfcoat.2015.03.052

17. Sousa RRM, Araújo FO, Costa THC, Nascimento IO, Santos FEP, Alves Jr. C, Feitor MC. Thin TiN and TiO2 film deposition in glass samples by cathodic cage. Materials Research. 2015;18(2):347-352. https://doi.org/10.1590/1516-1439.313914

18. Naeem M, Shafiq M, Zaka-ul-Islam M, Ashiq A, Díaz-Guillén JC, Shahzad M, Zakaullah M. Enhanced surface properties of plain carbon steel using plasma nitriding with austenitic steel cathodic cage. Materials \& Design. 2016;108:745-753. https:// doi.org/10.1016/i.matdes.2016.07.044

19. Vasu K, Krishna MG, Padmanabhan KA. Conductive-atomic force microscopy study of local electron transport in nanostructured titanium nitride thin films. Thin Solid Films. 2011;519(22):77027706. https://doi.org/10.1016/j.tsf.2011.05.052 